\title{
LEGISLATIVE APPORTIONMENT: MULTIMEMBER DISTRICTS AND FATR REPRESENTATION
}

\author{
W ALTER L. CaRpeneti $\dagger$
}

\section{INTRODUCTION}

In 1962 the Supreme Court overturned without expressly overruling a line of cases ${ }^{1}$ in which it had refused to reach the merits of many questions raised by legislative apportionment. ${ }^{2}$ In Baker v. Carr ${ }^{3}$ the Court found that federal courts had jurisdiction of the subject matter $^{4}$ and that malapportionment claims were justiciable, ${ }^{5}$ and opened

† A.B. 1967, Stanford University; J.D. 1970, University of California, Berkeley. Member, Alaska and California Bars.

1 E.g., Matthews v. Handley, 361 U.S. 127 (1959) (mem.) ; Hartsfield v. Sloan, 357 U.S. 916 (1958) (mem.) ; Radford v. Gary, 352 U.S. 991 (1957) (mem.) ; Kidd v. McCanless, 352 U.S. 920 (1956) (mem.) ; Anderson v. Jordan, 343 U.S. 912 (1952) (mem.) ; Tedesco v. Board of Supervisors, 339 U.S. 940 (1950) (mem.) ; MacDougall v. Green, 335 U.S. 281 (1948) (mem.); Colegrove v. Green, 328 U.S. 549 (1946).

The questions facing the Court in each of these cases were whether federal courts had jurisdiction of cases concerning legislative apportionment and whether the issues were justiciable. They were answered in the negative. Colegrove, supra, was the leading case in this line (subsequent cases routinely cited it in per curiam opinions), although a majority of the Justices taking part in that case were of the opinion that the issues were justiciable. The plurality opinion of Justice Frankfurter-commonly cited for the proposition that the issues were not justiciable-represented the views of only three Justices. Although Justice Rutledge personally believed this case to be non-justiciable, he felt bound by Smiley v. Holm, 285 U.S. 355 (1932), which he read as having decided that a case of this type was justiciable. Despite his finding of justiciability, he concurred on the ground that as a matter of policy, the Court should refuse to exercise its equity jurisdiction under the circumstances. 328 U.S. at 564-65. Justice Black, speaking for three Justices, dissented and would have decided for plaintiffs on the merits as well as on the justiciability claim. Id. at 568 .

2 The Supreme Court had acted in a number of cases dealing with apportionment or voting rights prior to 1962 , but they all reached the Court on questions other than pure apportionment alone. See, e.g., Gomillion v. Lightfoot, 364 U.S. 339 (1960) (whether denial to blacks of participation in city elections by redrawing city lines violates fifteenth amendment); Wood v. Broom, 287 U.S. 1 (1932) (whether 1911 Reapportionment Act's standards of population equality, compactness, and contiguousness for congressional districts were not still in effect); Smiley v. Holm, 285 U.S. 355 (1932) (whether governor's veto rendered state congressional redistricting act null); Carroll v. Becker, 285 U.S. 380 (1932) (same); Koenig v. Flynn, 285 U.S. 375 (1932) (same).

Further, when those cases (Smiley, Carroll, Koenig) dealing with congressional districting are omitted (see Black, Inequalities in Districting for Congress: Baker v. Carr and Colegrove v. Green, 72 YALE L.J. 13 (1962), for the proposition that there is strong justification for federal judicial activism where the composition of the federal legislature is concerned), not one of the apportionment cases before the Supreme Court between 1932 and 1962 was successful. R. Drxon, Democratic Representation: Reapportionment in Law and Politics 113-14 (1968) [hereinafter cited as DEMOCRATIC REPRESENTATION].

3369 U.S. 186 (1962).

4 Id. at $198-204$.

5 Id. at 208-37. 
the way for a series of attacks on virtually every type ${ }^{6}$ of districting and apportionment scheme ${ }^{7}$ used in America.

If justiciability was the first round, the Georgia Cases $^{8}$ and the Reapportionment Cases $^{9}$ of 1963-1964 represented the second round of the battle. In these cases the Court attempted to focus on the standards ${ }^{10}$ to be used in judging the constitutionality of an apportionment plan. ${ }^{11}$ From them emerged the catch-phrase "one man-

6 Not even single member legislative districts with substantially equal populations have been immune from attack. See Wright v. Rockefeller, 376 U.S. 52 (1964), aff'g 211 F. Supp. 460 (S.D.N.Y. 1962); notes 105-13 infra \& accompanying text. 11 infra.

7 For a partial list of the types of such schemes utilized in this country, see note

8 Wesberry v. Sanders, 376 U.S. 1 (1964) (apportionment plan that called for one congressional district to contain over twice the population of the average of all the others in the state violated U.S. Const. art. 1, \$2); Gray v. Sanders, 372 U.S. 368 (1963) (county-unit system utilized in primaries for state offices, which weights yotes cast in rural counties, violated the equal protection clause, U.S. CoNst. amend. XIV, § 1).

9 Reynolds v. Sims, 377 U.S. 533 (1964) (under the equal protection clause, seats in both houses in a bicameral legislature must be apportioned substantially on a population basis); WMCA, Inc. v. Lomenzo, 377 U.S. 633 (1964); Maryland Comm. for Fair Representation v. Tawes, 377 U.S. 656 (1964); Davis v. Mann, 377 U.S. 678 (1964); Roman v. Sincock, 377 U.S. 695 (1964); Lucas v. Forty-fourth Gen. Assembly, 377 U.S. 713 (1964).

10 Legal commentary following Baker v. Carr reached flood proportions, much of it devoted to the question of what standards the Court should utilize in deciding the multitude of apportionment cases being litigated at that time in the federal courts and soon to reach the Supreme Court. See, e.g., $A$ Symposium on Baker v. Carr, 72 YALE L.J. 7 (1962); Some Current Thinking on Voting Rights, 61 MiCH. L. Rev. 643 (1963) (symposium); Reapportionment Series, 38 Notre DaMr IAw. 367 (1963) (symposium); Dixon, Legislative Apportionment and the Federal Constitution, 27 LAw \& CoNTEMP. ProB. 329 (1962) ; McKay, Federal Analogy and State Apportionment Standards, 38 Notre DAME LAw. 487 (1963); Neal, Baker v. Carr: Politics in Search of Laze, 1962 Sup. Cr. Rev. 252.

In Reynolds, the Supreme Court did imply that some factors other than population equality might be considered, see note 15 infra, although the list of those factors specifically excluded from consideration is certainly more substantial: geographic area, economic interest groupings, political interest groupings, "other sorts of group interests," historical considerations, etc. 377 U.S. at 562-68, 579-80.

11 The ways in which legislators can create voting districts and apportion voters to them appear to be infinite. Some of the better-known plans utilize single member districts, see note 23 infra, multimember districts, see note 24 infra, floterial districts, weighted voting, unit-votes, ratio voting, and unholy combinations of these devices (and others) to present formidable problems to anyone-including courts-who would try to understand, let alone analyze them. For purposes of illustration, the eight apportionment cases decided by the Supreme Court in 1963-1964, see notes 8-9 supra, presented the following plans: mixed single member districts and multimember districts based primarily on county lines, with slight consideration given to population (Reynolds v. Sims, 377 U.S. at 545-51) ; mixed single member districts and multimember districts based on county lines and population, computed according to a series of ratios derived from calculations prescribed by the state constitution; mixed single member districts and multimember districts based primarily on county (or city) lines, with some consideration given to population (Maryland Comm. for Fair Representation v. Tawes, 377 U.S. at 664-68; Roman v. Sincock, 377 U.S. at 703-08); mixed single member districts and multimember districts based primarily on county lines and population, computed according to ratios prescribed by the state constitution (Lucas v. Forty-fourth Gen. Assembly, 377 U.S. at 724-25); single member districts based on county lines and geographical units with active disregard for population (Wesberry v. Sanders, 376 U.S. at 2 ) ; a county unit system based on county 
one vote," 12 and it quickly became the shorthand symbol for the requirement that the result of every apportionment method be "districts . . . as nearly of equal population as is practicable." 13 The adoption of this phrase proved to be well-founded, for in the years following the Reapportionment Cases, the unmistakable trend of reapportionment decisions has been in the direction of strict adherence to precise mathematical equality. ${ }^{14}$

The problems inherent in this unifaceted ${ }^{15}$ approach to an incredibly complex field have not been lost on commentators, ${ }^{16}$ lower

lines and utilizing an irregular sliding scale of unit votes to take population into account (Gray v. Sanders, 372 U.S. at 372).

Of course, these are only the apportionment plans themselves. Beyond lie the problems brought about by attempts to group voters under a given plan so as to increase the effective voting power of some at the expense of others-what is loosely referred to as gerrymandering.

12 The closest the Court itself came to the phrase was Justice Douglas' opinion for the Court in Gray v. Sanders, 372 U.S. 368, 381 (1963):

The conception of political equality from the Declaration of Independence, to

Lincoln's Gettysburg Address, to the Fifteenth, Seventeenth, and Nineteenth

Amendments can mean only one thing-one person, one vote.

13 Reynolds v. Sims, 377 U.S. 533, 577 (1964).

14 Swann v. Adams, 385 U.S. 440 (1967), significantly tightened the "substantial equality of population" requirement laid down by Reynolds. In Swann, the Supreme Court implied that only "de minimis" population variances between districts are acceptable "without a satisfactory explanation grounded on acceptable state policy." Id. at 444. In Duddleston v. Grills, 385 U.S. 455 (1965), the Court vacated and remanded for further consideration in light of Swamn a congressional districting plan where the maximum deviation from the average district was only $12.8 \%$; in Kirkpatrick v. Preisler, 385 U.S. 450 (1967), it sustained a district court which had nullified a congressional districting plan in which the maximum deviation was only $9.9 \%$. (For an explanation of the terms of measurement utilized in this field, see note 33 infra.) As one commentator summed up the trend:

[T] he arithmetic equality principle is tightening, ... special justifications

[for population variances] will be rigorously reviewed, and .. . the special

justifications themselves must not produce more than a "minor" variation ....

... The Court has characterized the reapportionment issue as being a matter only of equalizing gross population clusters, rather than as being one of achieving fair and effective political representation.

Democratic Representation, supra note 2, at 449. But see Abate v. Mundt, 403 U.S. 182 (1971).

15 Ironically, Reynolds, the case that announced the "substantial equality of population" principle, also hinted that other factors might validly be taken into account in drawing district lines. The key language was in fact quite broad:

So long as the divergences from a strict population standard are based on legitimate considerations incident to the effectuation of a rational state policy, some deviations from the equal-population principle are constitutionally permissible...

377 U.S. at 579.

The Court mentioned some of these "legitimate considerations": "A State may legitimately desire to maintain the integrity of various political subdivisions," to "provide for compact districts of contiguous territory," to "achieve some flexibility by creating multimember or floterial districts"; it may also accord "political subdivisions" some independent representation in at least one body of the state legislature . . . 377 U.S. at 578-80. However, these and other factors have been reduced to little importance in reapportionment doctrine, see note 14 supra.

16 See, e.g., Dearocratic Representation, sipra note 2, at 272-73; A. DE Grazia, Apportionment aNd Representative Govern MENT 53-63 (1963) ; Black, Iinequities in Districting for Congress: Baker v. Carr and Colegrove v. Green, 72 YALE L.J. 13, 17 (1962). 
courts, ${ }^{17}$ and many members of the Supreme Court. ${ }^{18}$ The central problem may be stated simply: equal representation ${ }^{19}$ does not necessarily mean fair representation. Although fair representation should be the goal of legislative apportionment, "one man-one vote" does not necessarily lead to fair representation. Assuring that each legislator represents an equal number of constituents by no means guarantees that the various groups of interests in the whole polity will be fairly represented. $^{20}$

Thus, the problem may be seen as the result of an undue emphasis on the quantitative aspects of equal representation, that is, equalizing district size via "one man-one vote," while turning away from the really difficult considerations : what makes a given apportionment plan "representative"? If the Court truly intends to establish equal representation, it must give recognition to standards other than population size. The problems presented by moving away from population as the sole determinant of equal representation-and the formulation of the standards to supplement it-may be seen as the third, and in many ways the most important, round of the reapportionment struggle.

17 See, e.g. Hughes v. Maryland Comm. for Fair Representation, 241 Md. 471, 486,217 A.2d 273,281 , cert. denied, 384 U.S. 950 (1966), upholding a plan that contained a maximum deviation of $36 \%$ :

According to the decisions, $36 \%$ is, of course, high. However, . . the Supreme Court has recognized that some divergences from population-based representation are permissible, so long as they are the result of legitimate considerations incident to the effectuation of a rational state policy, based principally upon population. .. [W] are unwilling to strike down [this plan] for the comparatively few "suspect" variances, which, in our view, clearly result from an earnest effort to accomplish a reasonable statewide apportionment, and, at the same time, accord some slight independent representation to individual, existing political subdivisions.

By the end of 1966, at least 25 states had judicially approved apportionment plans in which districts in at least one house exceeded a $15 \%$ variation from the average size district. DEMOCRATIC REPRESENTATION, supra note 2 , at 442.

18 Most of the major reapportionment decisions since Baker have recognized, at least implicitly, the difficulty of relying only on the population standard. See, e.g., Reynolds v. Sims, 377 U.S. 533 (1964). Moreover, powerful dissents have made the point clearly. See, e.g., Baker v. Carr, 369 U.S. 186, 323 (1962) (Frankfurter, J., dissenting); Reynolds v. Sims, 377 U.S. 533, 622-24 (1964) (Harlan, J., dissenting in all six Reapportionment Cases) ; Lucas v. Forty-fourth Gen. Assembly, 377 U.S. 713, 742 (1964) (Clark, J., dissenting); id. at 749 (Stewart, J., dissenting).

19 The phrase was apparently used to refer only to mathematical equality in district size. Reynolds v. Sims, 377 U.S. 533, 576 (1964). However, in the same opinion, Chief Justice Warren made numerous references to an apparently broader goal, see, e.g., id. at 565-65: ". . the achieving of fair and effective representation for all citizens is concededly the basic aim of legislative apportionment . . . ." (emphasis added).

20 See Sickels, Dragons, Bacon Strips and Dumbbells-Who's Afraid of Reapportionment?, 75 Y ALE L.J. 1300 (1966), for a graphic example of how a judicial command to reapportion may present a legislature with a golden opportunity to put a vicious gerrymander beyond judicial scrutiny (at least under Reynolds) by complying with the mathematical requirements of the Reapportionment Cases, while utterly disregarding "fair" representation. See also A. DE GRAzIA, ApPORTIONMENT AND REPRESENTAtIVE Government 57 (1963). 
One reapportionment scheme that presents these problems of fair, rather than merely arithmetically equal representation, employs multimember legislative districts. Under such a system a city, county, or other area, which is numerically entitled to more than one representative in the state legislature, is not subdivided into the appropriate number of individual districts, but rather elects its delegation on an at large basis. In Whitcomb v. Chavis, ${ }^{21}$ plaintiffs unsuccessfully attacked a multimember apportionment scheme on the ground that it unconstitutionally diluted their representation. The case suggests that the Supreme Court is not yet ready to establish standards beyond strict mathematical equality.

Chavis was an attack, successful in the district court, ${ }^{22}$ on an apportionment scheme that combined the use of single member ${ }^{23}$ and multimember ${ }^{24}$ legislative districts. Plaintiffs argued that multimember districts discriminated against them in various ways. ${ }^{25}$ The district court was most impressed by the claim that a large, cognizable urban minority with similar legislative interests (the black ghetto population of Marion County, Indiana) was effectively precluded from electing its share of the county's eight state senators and fifteen assemblymen because Marion County representatives were elected at large. Finding

21403 U.S. 124 (1971).

22305 F. Supp. 1364 (S.D. Ind. 1969).

23 A single member district is a district that elects one representative to the legislative body. This is the most common type of legislative district used in this country. Although as of November $1970,54 \%$ of the upper houses and $70 \%$ of the lower houses of state legislatures contained some multimember districts, most legislators were elected from single member districts. See Natronal MUNICIPAL LEAGUE, APPORTIONMENT IN THE NINETEEN SixTIES (1970).

24 A multimember district is one which elects more than one representative to the legislative body. Such districts are typically used to represent cities that, because of their population, are assigned more than one representative. Rather than break the city up into a number of districts, the legislature (or apportioning body) instead assigns all of the representatives to the whole city, with each running at large. Many legislatures have found in multimember districts a constitutionally valid way of complying with the Supreme Court's equal-populations standard while retaining a large degree of bloc or "interest" representation.

On the other hand, the anti-minority effects of multimember districts have been recognized at least since 1842 , when Congress provided that representatives to the Federal House must be elected by districts, "no one district electing more than one Representative." Act of June 25,1842 , ch. $47, \S 2,5$ Stat. 491 . Commentary on this law left little doubt that the reason for it was:

the wisdom and justice of giving, as far as possible, to the local subdivisions of the people of each state, a due influence in the choice of representatives, so as not to leave the aggregate minority of the people in a state, though approaching perhaps to a majority, to be wholly overpowered by the combined action of the numerical majority, without any voice whatever in the national councils.

1 J. Kent, Commentaries on American Law $* 230$ n.c (5th ed. 1844). And in recent years the trend has been for most states to abandon the use of multimember districts. Dixon \& Hatheway, The Seminal Issue in State Constitutional Revision: Reapportionment Method and Standards, 10 WM. \& MARY L. REv. 888, 903 (1969).

25 See text accompanying notes 70-72 infra. 
in this scheme unconstitutional minimization of black voting power, ${ }^{26}$ the district court threw out the state's apportionment plan. ${ }^{27}$ The Supreme Court reversed, holding that plaintiffs had failed to prove that they had less opportunity to participate in the electoral process or that their interests went unrepresented or were poorly represented in the legislature. Fearing a result which would "spawn endless litigation," 28 the Court declined to hold either that multimember districts are inherently invidious or that the multimember district in Chavis operated in such a fashion.

Although there are many ways an apportionment plan can interfere with fair representation, this Article is limited to considering how a court should approach a plan that is attacked as unconstitutionally discriminatory against a minority within a multimember district. It begins with an examination of the history of multimember district litigation leading up to Chavis and follows with an explanation and criticism of the district court and Supreme Court opinions in that case. It then attempts to formulate an appropriate legal standard for the adjudication of multimember district litigation, drawing upon doctrines and policies developed in reapportionment and related fields of law.

\section{Past Multimember District Cases}

The doctrinal basis of the district court opinion in Chavis was not the creation of the three-judge court. On the contrary, the opinion was a response to dicta in earlier Supreme Court cases concerning multimember districts.

The first case to mention multimember districts in the post-Baker era was Reynolds $v$. Sims. ${ }^{29}$ It did not dwell at great length on the subject, but only attempted to show that the rule it announced-that both houses of a state legislature must be apportioned on an equal population basis-did not spell the end of bicameralism. ${ }^{30}$ It did this by showing that differences "in the composition and complexion" of the two houses of a state legislature could be maintained by a number of devices, including the use of "at least some multi-member districts" in one of the legislative houses. ${ }^{31}$

26305 F. Supp. at 1369.

27 Id. at 1399 . The court allowed approximately 60 days for the Indiana legislature and governor to reapportion in conformity with its opinion. Id. at 1400 . When this time had passed and the state had taken no action towards reapportionment, the court, which had retained jurisdiction, reconvened and proceeded to reapportion both the state senate and house. Chavis v. Whitcomb, 307 F. Supp. 1362 (S.D. Ind. 1969).

28403 U.S. 124, 157 (1971).

20377 U.S. 533 (1964).

$30 \mathrm{Id}$. at $576-77$.

31 Id. The Court's opinion in fact referred to the possible use of multimember districts a second time: "Single-member districts may be the rule in one State, while another State might desire to achieve some flexibility by creating multimember districts or floterial districts." Id. at 579 (footnote omitted). 
The Court next looked at multimember districts in Lucas v. Fortyfourth General Assembly of Colorado, ${ }^{32}$ a companion case to Reynolds. There a voter-approved "federal" plan for the state legislature was held unconstitutional on the ground that the population variances ${ }^{33}$ it contained were impermissibly high. ${ }^{34}$ Probably the Court wanted to build a stronger case, however, since the plan had been approved by the voters, ${ }^{35}$ and accordingly it endeavored to show that the original election which had offered two plans to the voters had not really offered a broad enough choice. To support this rather narrow point, the Court asserted that the rejected equal population plan had the "undesirable feature" of electing representatives at large ${ }^{36}$ from all counties having more than one representative, while the approved federal plan had no such multimember districts. ${ }^{37}$ It then spelled out what was deemed objectionable about multimember districts: 1) they necessitated long and cumbersome ballots which made intelligent choice difficult for the voters; 2) "[n]o identifiable constituencies reithin the populous counties resulted"; and 3) residents of the more populous counties had "no single member . . . elected specifically to represent them." 38 That the Court was not convinced that these features were constitutionally proscribed is evident

32377 U.S. 713 (1964).

33 The most commonly used measurement to determine population equality is the population variance ratio. This represents the ratio between the largest district and the smallest. As such it gives a picture only of the extremes, which may or may not accurately reflect the actual situation. For example, if there are 98 districts each of 100 population, 1 of 190 and 1 of 10 , the population variance $(19: 1)$ is gross but the actual overall disparity is not, in that the overwhelming majority of people live in districts of the proper size.

For a comprehensive treatment of the different measures of equality used in legislative districting, see DEMOCRATIC REPRESENTATION, supra note 2, at 452-54.

34377 U.S. at 734-35. The variance found to exceed the equal population standard was 3.6 to 1 in the senate. (That is, the largest district was 3.6 times as large as the smallest.) Id. at 728. The Court refused to pass on the question of whether the house apportionment-which yielded a maximum population variance ratio of 1.7 to $1, i d$. at 727 -comported with the standard, finding this to be unnecessary because there was "no indication that the apportionment of the two houses . . . is severable." Id. at 735 .

35 Lucas was the only one of the Reapportionment Cases in which the plan under attack had been specifically ratified by the voters. The vote in favor was almost 2 to 1 . Moreover, in the same election a proposal embodying the equal population formula for both houses was defeated by more than a 2 to 1 ratio. 377 U.S. at 717 . The Court was unmoved:

An individual's constitutionally protected right to cast an equally weighted vote cannot be denied even by a vote of a majority of a state's electorate, if the apportionment scheme adopted by the voters fails to measure up to the requirements of the Equal Protection Clause.

Id. at 736 .

36 Id. at 731-32. This "undesirable feature" was then in effect in Colorado, but the Court seemed to assume that opposition to it was a significant factor in the defeat of the equal population plan. Id.

37 Id. Hence, a voter could not opt for single member districts and the equal population plan. "Thus, neither of the proposed plans was, in all probability, wholly acceptable to the voters in the populous counties . . . Id. at 732 .

$38 \mathrm{Id}$. at $731 \mathrm{n} .21$. 
from the Court's statement that it was merely noting their undesirability:

We do not intimate that apportionment schemes which provide for the at-large election of a number of legislators from a county, or any political subdivision, are constitutionally defective. Rather, we merely point out that there are certain aspects of electing legislators at large from a county as a whole that might well make the adoption of such a scheme undesirable to many voters residing in multimember counties. ${ }^{39}$

In both Reynolds and Lucas the question of multimember districts was tangential to the holding of the case. The first chance for full consideration of the issue was presented in Drew $v$. Scranton, ${ }^{40}$ in which a federal district court had invalidated a Pennsylvania plan combining single member district, multimember district and mixed single member and multimember district counties in a pattern for which there was no "legislative history or other explanation." 41 In the absence of any justification, the federal court concluded that the districting was "either the result of gerrymandering for partisan advantage . . . or . . . wholly arbitrary and capricious." ${ }^{42}$ The court then found that voters in multimember districts were both advantaged and disadvantaged visà-vis single member district voters. Advantage resulted from having more than one legislative representative. ${ }^{43}$ Disadvantage was found in the voter's lessened opportunity for personal contact with his representatives ${ }^{44}$ and in the possibility that minority interests would be submerged. ${ }^{45}$ The court held that under the circumstances the multimember districts violated the equal protection clause because voters in those districts had more power than voters in single member districts. In addition to this holding based on a complex mathematical argument, the court found that under certain circumstances the power of groups

39 Id.

40229 F. Supp. 310 (M.D. Pa. 1964).

$41 \mathrm{Id}$. at 326 .

$42 I d$.

43 Id. at 327 .

44 Id.

$45 \mathrm{Id}$. The district court's formulation of the minority submergence theory was the earliest judicial recognition of the problem:

Minority groups living in particular localities may well be submerged in elections at large but can often make their voting power much more effective in the smaller single member district in which they live.

Id. This statement assumes that members of minority groups share enough voting interests in common to justify treating them as cognizable groups for purposes of apportionment law. That premise is found in much judicial commentary in this area and is adopted for limited purposes in this paper. It is clearly open to question, however, and deserves separate treatment. 
within the multimember districts would be submerged, leaving those voters with less influence on the electoral process. ${ }^{46}$ Although the case clearly presented these issues, the Supreme Court did not hear oral argument. It vacated and remanded ${ }^{47}$ when the state supreme court showed a willingness to enter the field.

Shortly after Lucas, the Court decided the leading multimember district case. The constitutionality of multimember districts was drawn immediately into question, but the procedural aspects of the case precluded a clear holding on the merits. In Fortson $v$. Dorsey, ${ }^{48}$ a federal district court in Georgia had granted summary judgment ${ }^{49}$ for plaintiffs on their complaint of invidious discrimination resulting from the use of multimember districts in populous counties of the state. Georgia elected its state senators from districts which in less populous areas were composed of one or more counties. Urban counties, with more than one senatorial district because of their greater population, were divided into as many as seven districts. For these counties, however, elections were conducted at large throughout the county (the only requirement being that a senator reside in the district he "represented"). Plaintiffs claimed, and the district court agreed, that they were discriminated against vis-à-vis voters in single member districts. Whereas plaintiffs had to join with outsiders to elect their senators, voters in single member districts did not have to do so. ${ }^{50}$ The Supreme Court reversed. Citing Reynolds on the permissibility of having "at least some multimember districts" in one state legislative house, ${ }^{51}$ it reiterated that the main standard is substantial equality of population ${ }^{52}$ and found that the Georgia scheme met this standard. ${ }^{53}$

The Court was careful to note that it was adjudicating the appeal of a summary judgment; thus it was saying only that the use of multimember districts was not bad per se. ${ }^{54}$ It did, however, begin to open the door:

46 The court actually "held" that the multimember districts in this case violated equal protection because voters in single member districts were deprived of voting power equal to that held by multimember district voters. Id. at 328 . However, it did "find" that multimember district voters in certain circumstances were left with less power than single member district voters, $i d$. at 327 ; this is the theory developed in the later cases, see, e.g., text accompanying notes 48-50 infra, and it is the theory analyzed in this paper. 1964).

47379 U.S. 40 (1964), vacating and remanding 229 F. Supp. 310 (M.D. Pa.

48379 U.S. 433 (1965).

49 Dorsey v. Fortson, 228 F. Supp. 259 (N.D. Ga. 1964).

$50 \mathrm{Id}$. at 261.

51379 U.S. at 436 (citing Reynolds v. Sims, 377 U.S. 533, 577 (1964)).

$52 I d$. at 436 (quoting Reynolds v. Sims, 377 U.S. 533, 579 (1964)).

53 Id. at $437-38$.

54 Id. at 438-39. Saxbe, Criteria Established by Court Decisions, in REAPPORTIONING Legislatures 24,32 (H. Hamilton ed. 1966). 
[O]ur opinion is not to be understood to say that in all instances or under all circumstances such a system as Georgia has will comport with the dictates of the Equal Protection Clause. It might well be that, designedly or otherwise, a multi-member constituency apportionment scheme, under the circumstances of a particular case, would operate to minimize or cancel out the voting strength of racial or political elements of the voting population. When this is demonstrated it will be time enough to consider whether the system still passes constitutional muster. ${ }^{55}$

Although the key language is grammatically equivocal dictum, there was nevertheless a clear suggestion that, under the described conditions, a multimember district plan might be declared unconstitutional. Certainly if the Court did not intend this suggestion it is difficult to understand the purpose of its statement. Moreover, the doctrine it implied was not a startling one: the Court would protect the voting power of a minority group upon a showing that its power was being subverted by a particular apportionment scheme. Because the plaintiffs in Fortson failed to show such an adverse effect, the Court would not act. Thus, under this reading of the decision, the failure in plaintiffs' case was one of proof.

The quoted statement did suggest one other question-besides what kind of proof is necessary-in regard to multimember districts. That is, whether there is any distinction to be made between racial and political elements of the population.

Since no attempt was made to show submergence in this case, ${ }^{56}$ (because plaintiffs had prevailed below on summary judgment), the Court could only pose these issues for future consideration. From the point of view of those attacking multimember districts on equal protection grounds, it is probably unfortunate that this was the first case presenting the problem of such districts. A case based on the argument of submergence might have led the Court at least to adopt a kind of strict scrutiny standard when dealing with multimember districts.

55379 U.S. at 439 . Burns v. Richardson, 384 U.S. 73 (1966), discussed at text accompanying notes 57-68 infra, put this more specifically:

- . apportionment schemes including multi-member districts will constitute an invidious discrimination [where Fortson's proof requirements are met].

Id. at 88 (emphasis added).

56 The Court rejected plaintiffs' assertion that a senator wanted by nobody in one district could be foisted upon that district by the voters of the other districts within the county as "highly hypothetical": there had been no showing that this was likely given the political makeup of the district and the rest of the county. 433 U.S. at 43738. Had it been shown that such an occurrence was likely, it is not clear what the Court would have done. This would have been sufficient to reach the general problem of submergence of the votes of a group only if the borders of that district were coterminous with that of a provably distinguishable "political or racial element." 
Fortson left unclear how much and what kind of proof would be necessary to overturn a multimember district plan. Burns $v$. Richardson $^{57}$ decided a year later by the Supreme Court, shed some light on the situation. Again, however, the Court reversed a district court ${ }^{58}$ finding of unconstitutionality based on the use of multimember districts, and so its comments on what constitutes adequate proof to invalidate the use of such districts are dicta.

In Burns, the district court rejected a plan for apportionment of the Hawaii Senate because it utilized multimember districts almost exclusively, ${ }^{59}$ and because many of the new senatorial districts coincided with lower house districts. ${ }^{60}$ The court found that this scheme built monoliths into Hawaii representation, and noted that the plan also failed to take into account "community of interests, community of problems, socio-economic status [and] political and racial factors." 61 Again the Supreme Court reversed; again the narrow holding of the case relied on the Reynolds dictum. ${ }^{62}$ Since plaintiffs had not made the necessary factual showing, ${ }^{63}$ they could not prevail. ${ }^{64}$

$5 \pi 384$ U.S. 73 (1966).

58 Holt v. Richardson, 240 F. Supp. 724 (D. Hawaii 1965), rev'd sub nom. Burns v. Richardson, 384 U.S. 73 (1966).

59 In this regard, see the proposed apportionment of senators, $240 \mathrm{~F}$. Supp. at 727 , placing 24 of the 25 seats in multimember districts, of which the largest were 4-member districts. One cannot help but feel, however, that this plan was far superior to an earlier proposal calling for the state's 25 senators to be apportioned among districts of the following sizes: $10,9,2,2,1,1 . I d$. at 726 . Nonetheless, the court rejected the later as well as the earlier proposal.

60 Id. at 730.

61 Id. This opinion was written before the Supreme Court settled upon the equal population standard as the only permissible standard. See notes 10-14 supra \& accompanying text. Yet the opinion had the benefit of Reynolds v. Sims, 377 U.S. 533 (1964), which said that equal population was the only factor that must be taken into account. The district court nonetheless maintained that:

[C]ommunity of interests, community of problems, socio-economic status, political and racial factors . . must be considered, and not only must the electoral districts be laid out with the totality of those factors having been taken into consideration, but even more, the sum total of all of the districting must result in substantial equality of meaningful representation to each and all of the voters of the State.

240 F. Supp. at 730 (emphasis added). This represents probably the clearest call for judicial activism to define the requirements of "equal representation" beyond mere population equality. Obviously, the Hawaii district court has not been followed. See text accompanying notes 10-14 sipra.

62 See text accompanying note 51 supra.

63

[T] he demonstration that a particular multi-member scheme effects an invidious result must appear from evidence in the record. . . . That demonstration was not made here.

384 U.S. at 88. theory:

04 In a footnote to this section, the Court even advanced a possible plaintiff's

There may, for example, be merit in the argument that by encouraging block voting multi-member districts diminish the opportunity of a minority party to win seats. But such effects must be demonstrated by evidence.

Id. at 88 n.14. 
Citing Fortson v. Dorsey, the Court said that when the equal population requirements of Reynolds are met:

[A]pportionment schemes including multi-member districts will constitute an invidious discrimination only if it can be shown that "designedly or otherwise, a multi-member constituency apportionment scheme, under the circumstances of a particular case, would operate to minimize or cancel out the voting strength of racial or political elements of the voting population." 65

This did little to clarify Fortson beyond making it evident that such an apportionment scheme could be held unconstitutional only under the described circumstances. On the question of intent, the Court said that the plaintiff in Burns failed to "supply evidence that the multi-member districting was designed to have or had the invidious effect necessary to a judgment of the unconstitutionality of the districting." 66 That proof of both intent and effect would not be necessary, but that either would be sufficient, seems clear from the additional statement that a legislative plan would be subject:

to constitutional challenge only upon a demonstration that [it] was designed to or would operate to minimize or cancel out the voting strength of racial or political elements of the voting population. ${ }^{67}$

In relation to this, the Court stated:

It may be that this invidious effect can more easily be shown if, in contrast to the facts in Fortson, districts are large in relation to the total number of legislators, if districts are not appropriately subdistricted to assure distribution of legislators that are resident over the entire district, or if such districts characterize both houses of a bicameral legislature rather than one. ${ }^{68}$

These three criteria seemingly provided insight into the type of information the Court would examine in the future. But Burns did not begin to provide a meaningful test, for in Burns itself the apportionment plan met each of these three negative criteria, but was found constitutional in the absence of proof of harmful effect.

Although the Court continued to reject challenges to multimember districts based on plaintiffs' failures to sustain the burden of proof, ${ }^{69}$ it

$65 \mathrm{Id}$. at 88 .

66 Id. at 88-89.

67 Id. at 89 (footnote omitted).

68 Id. at 88.

69 Kilgarlin v. Hill, 386 U.S. 120, 121 (1967) (per curiam) aff'g on the isste of proof Kilgarlin v. Martin, 252 F. Supp. 404 (S.D. Tex. 1966). 
seemed, after Burns, that only the right case was lacking, one in which plaintiffs could walk through the door which the Court had been opening ever wider since Reynolds. By all odds, Whitcomb $v$. Chavis was that case. The district court agreed. But the Supreme Court did not, and rejected every aspect of the lower court's opinion dealing with the constitutionality of multimember districts. At this point it is appropriate to examine more closely Whitcomb v. Chavis.

\section{Whitcomb v. Chavis}

\section{A. The District Court Opinion}

Chavis seemed to be meticulously prepared in response to the developments outlined in part II. Plaintiffs were chosen in a way that included representatives of every conceivable aggrieved interest: blacks living in the multimember district but outside the ghetto, those inside the ghetto, those in another district, whites (Republican) living in the suburbs yet still in the district, and independent voters within the district. $^{70}$ The causes of action they advanced were likewise diverse. Blacks in the ghetto argued "submergence" 71 of their votes. Those outside the ghetto argued that the only chance for someone to represent their point of view was for the ghetto to have effective representation since the "interests and voting propensities" of the two groups approximate each other. Blacks entirely outside the district argued that the voters of the large multimember district enjoyed a subtle mathematical advantage in voting for their representatives. ${ }^{72}$ White suburban Republicans claimed a submergence effect similar to that claimed by black ghetto residents. Finally, independent voters claimed they were simply confused-frustrated in their efforts to vote for the man, not the party, by long ballots and the dominance of the parties over the nomination process.

Faced with this onslaught of parties and theories, the district court began its analysis by summarizing the cases and from them determining

70305 F. Supp. 1364, 1367 (S.D. Ind. 1969).

71 This is the most serious of the various complaints, for it rests on the allegation that certain voters are denied voting power solely on the basis of race. As the court said, these plaintiffs "are alleged to be part of a cognizable interest group which regularly engages in bloc voting but whose bloc voting is cancelled out ...." Id. The opinions in both the district court and Supreme Court were based primarily on this complaint of racial submergence.

72 The claim was based on the contention that a single voter's voting power rests on his opportunity to cast a tie-breaking, or "critical" vote, and the mathematical assertion that the opportunity to cast a critical vote does not vary in direct inversion to the size of the voter population. Thus, residents of multimember districts (which are alloted seats in direct proportion to population size) are favored vis-à-vis voters in single member districts. The mathematical basis for this theory is explained in Banzhaf, Multi-Member Electoral Districts-Do They Violate the "One Man, One Vote" Principle?, 75 Y ALE L.J. 1309 (1966). 
the legal standard to be applied. It concluded that "The teaching of Fortson and Burns is that inherent discrimination is not apparent on the face of any multimember districting scheme, under the Equal Protection Clause," and that the choice between single member districts and multimember districts is a political one to be made by the state legislature and to be disturbed by the courts "only upon specific proof that the adopted scheme of districting is actually functioning in a manner that minimizes or cancels out the voting strength of a cognizable racial or political element of the voting population." 73

The evidence adduced at trial was voluminous. ${ }^{74}$ Both sets of parties brought forth data that afforded a detailed racial, social and economic profile of the district in question. The first fact to be determined was the existence of a cognizable racial element within the multimember district, which would fit the criteria set forth by Fortson and Burns. The court first defined the word "ghetto" as:

A primarily residential section of an urban area characterized by a higher relative density of population and a higher relative proportion of substandard housing than in the overall metropolitan area which is inhabited predominantly by members of a racial, ethnic, or other minority group, most of whom are of lower socioeconomic status than the prevailing status in the metropolitan area and whose residence in the section is often the result of social, legal, or economic restrictions or custom. ${ }^{75}$

With these standards in mind, the court presented exhaustive charts, prepared from the parties' evidence. The primary areas of investigation depicted were race, housing, and social and economic characteristics; each of these fields was subdivided. The charts documented the existence of a ghetto within the Center Township area of Indianapolis.

This finding was crucial, for it proved to the court the existence and pinpointed the location of a large group of voters who, by definition, had significantly different interests from the other voters in the large multimember district that encompassed Marion County. From its finding the court deduced that:

Each of the statistical differences represents compelling interests in such legislative areas as urban renewal and rehabilitation, health care, employment training and opportunities,

73305 F. Supp. at 1370.

74 See id. at 1375-78, 1381-84, 1393-99, consisting solely of demographic tables and charts, and census maps of the area in question.

$75 I d$. at 1373. 
welfare, and relief of the poor, law enforcement, quality of education, and anti-discrimination measures. ${ }^{78}$

The same compelling interests in these legislative areas were not to be found outside the ghetto. This finding is highly significant, for it effectively translates into collective terms the issue of voting rightsrights which have traditionally been considered an individual interest.

Next, the court considered evidence of "representational inequalities." It examined the place of residence of legislators elected from the district for a period of ten years, and found that a disproportionately high percentage, almost fifty percent, lived in one upper-middle class suburban area containing about fifteen percent of the population, while the Center Township ghetto, with about eighteen percent of the population, had a very low proportion, about five percent, of the legislators. ${ }^{77}$

The court lastly considered the role of political parties in the elections. It found that for any candidate to be elected to the General Assembly from the district, his or her party must prevail in the election as a whole. ${ }^{78}$ This winner-take-all effect may account for the conclusion that Marion County legislators tend "to maintain a common, undifferentiated position." According to the court this coalescing of positions prevented "representation of a substantial, though minority, interest group within the common constituency." "79 The only basis for this conclusion was the testimony of one of the plaintiffs, a former state senator, that "a legislator elected from Marion County is hesitant to express the interest of residents of the Center Township ghetto unequivocally in the legislative chambers, though he may believe it proper that those interests be furthered." 80

Testimony also tended to show that the county political organizations exerted a "pervasive influence" over the nomination of candidates. The court asserted that the multimember nature of the district contributed to this, and said that the ability of candidates with sectional attractiveness to overcome the party's primary recommendations would increase if single member districts were created. The court also referred to the lengthy ballots necessitated by the large multimember district,

$76 \mathrm{Id}$. at 1380 .

77 Id. at 1385 .

78 This was the court's conclusion, drawn from evidence that since 1920 only about $1 \%$ of the successful candidates for the Indiana General Assembly from Marion County were from the overall losing party. Id. The winner-take-all effect of multimember districts is enhanced where party organizations are strong and voters tend to vote a straight party ticket. Thus, for example, the Republicans captured none of the 15 assembly seats from Marion County in the 1964 election although they won $48.7 \%$ of the vote. Whitcomb v. Chavis, 403 U.S. 124, 134 n.11 (1971).

79305 F. Supp. at 1385.

80 Id. at 1386 ; see $i d$. at 1390 . 
and the difficulty thus presented to even the conscientious voter in making a rational selection. ${ }^{81}$

This evidence led the district court to four stated conclusions of fact. The court determined that black voters in the ghetto were unable "to be assured of the opportunity of voting for prospective legislators of their choice [in the general election] . . . ." 82 This conclusion was relevant for it said that blacks are effectively precluded from having their interests represented. An examination of the evidence, however, shows that the conclusion was not warranted: there was no direct evidence that candidates in the general election were disfavored in the ghetto. Rather, the court assumed that the ghetto had "preferred candidates" (whereas in reality it may have been divided among a number of candidates), and then surmised that these candidates did not survive the primaries. The necessary evidence should have been available. It may have taken no more than a showing that candidates who received a large majority of the ghetto votes consistently lost in the primary because of the vote from outside the ghetto. Yet that showing was not made.

The court then found an "absence of any particular legislator accountable to the [ghetto] voters for his legislative record." 83 It is hard to see the relevance of this finding. That is always the situation with multimember districts: none of the representatives is specifically accountable to any sub-area within the district. Since the Supreme Court has said that multimember districts are not per se unconstitutional, ${ }^{84}$ and since lack of narrowly local accountability is by definition an attribute of all multimember districts, this claimed shortcoming in Chavis cannot be a constitutional defect.

Finally, the court noted the conditions Burns said might make it easier to show that invidious discrimination is present in an apportionment scheme with multimember districts. The court found that the county elected a large percentage of the total number of state legislators, was not subdivided to insure representatives from varying areas within the district, and the same multimember district applied to both houses of the state legislature. Thus, invidious discrimination might be more easily shown because of the presence of these aggravating conditions, but as in Burns itself, these factors were not decisive.

The lower court opinion, then, although it drew upon impressive evidence, contained serious weaknesses. There was no direct proof that

$81 \mathrm{Id}$. at $1385-86$.

$82 I d$. at 1386.

83 Id. at 1385.

84 See Fortson v. Dorsey, 379 U.S. 433 (1965). 
ghetto voters were denied the opportunity to vote for preferred candidates in the general election. There was no direct proof that ghetto voters went unrepresented by virtue of legislators' reluctance to oppose the party line on various issues. There was not even the best proof available that the ghetto's choices at the general election were frustrated. ${ }^{85}$ Finally, the court's finding that no legislator was specifically accountable to the ghetto was irrelevant, since lack of accountability to sub-districts is characteristic of all multimember districts. The lower court went too far, finding unconstitutional submergence of ghetto interests when the evidence did not fully justify it.

\section{B. The Supreme Court Opinion}

If the district court went too far, the Supreme Court did not go far enough. The Court reversed the lower court on all issues concerning the constitutionality of the Marion County multimember district on the grounds that plaintiffs had failed to prove their case. The Court did not, however, base its decision on the precise weaknesses of proof in the lower court's opinion pointed out above. Instead it found that plaintiffs' failure to prove their case rested on their failure to prove that they were "being denied access to the political system." ${ }^{86}$

Access, opportunity, the chance to participate-this is the basic thread running through the opinion. Cancellation of voting strength, the Court insisted, was a "mere euphemism for political defeat at the polls" ${ }^{87}$ where there was no evidence either that blacks had been regularly excluded from the slates of both the major political parties, or that they had not been allowed "to register to vote, to choose the political party they desired to support, to participate in its affairs or to be equally represented on those occasions when legislative candidates were chosen." 88 Plaintiffs' complaint was reduced in the eyes of the Court to dissatisfaction with "the disaster of losing too many elections." 89

What happened, one might ask, to the apparent promise in Fortson and Burns to deal with a multimember district scheme which "design-

85 A method by which a trial court could ascertain whether the choice of a group of voters is frustrated is outlined at text following note 137 infra.

86403 U.S. at 149.

$8 \pi$ Id. at 153 .

88 Id. at 149. This characterization of plaintiffs' case reflects the fundamental difference in approach between the Supreme Court and the district court. The latter's finding that ghetto residents shared compelling legislative interests not found outside the ghetto indicates that the district court looked at the case in terms of group dynamics and group interests. The Supreme Court's insistence on assessing the opportunity of members of the group to vote and otherwise participate in the political process indicates that it looked at the case in terms of the individuals' rights as individuals.

$89 \mathrm{Id}$. at 153. 
edly or otherwise . . . would operate to minimize or cancel out the voting strength of racial . . . elements of the voting population." 90 In those decisions there had been no hint that the Court was thinking only of the most obvious forms of denial of access to the political processes.

In Chavis, the Court first dealt with the claim not squarely sustained by the district court that the multimember district gave to its voters an unconstitutional advantage by enabling them to influence the election of more legislators than voters in single member districts. This position, the Court concluded, remained highly theoretical, as the principal support relied on was an abstract mathematical demonstration. ${ }^{91}$ The position was not sustained either by the findings of the trial court or the record before the Court.

Turning then to the principal claim that the voting strength of ghetto residents within Marion County had been cancelled, the Court noted first that there had been no suggestion of purposeful discrimination. But that factor was arguably unnecessary under Fortson, which spoke of results achieved "designedly or otherwise." The opinion correctly noted that the case was outside the reach of decisions such as Sims v. Baggett ${ }^{92}$ in which an apportionment plan was held unconstitutional because evidence established legislative purpose to prevent the election of blacks to House membership. It failed, however, to articulate the Court's reasons for departing from the standard suggested by Fortson.

The Court then rejected the implication of invidious discrimination suggested by the fact that the number of ghetto residents who were legislators was not in proportion to the ghetto population. To justify a finding of discrimination it was necessary to show that ghetto residents had less opportunity to participate in the political process than other voters in the district. Absent such evidence, plaintiffs could not prevail. To negate the inference of discrimination, the opinion at this point relied heavily on the existing availability of access to the political process. It argued that any voters - whether they voted in single member or multimember districts-who backed a losing candidate could make the same charges plaintiffs had made. The deciding factor in determining the constitutionality of any apportionment plan should be whether all voters have an "equal opportunity to participate in and influence the selection of candidates." 93 
Of course, showing a denial of the chance to participate in the political process should be enough to establish a cause of action, but should it be the only way a plaintiff may successfully attack a multimember district? Fortson and Burns did not suggest this. Indeed, the salient characteristic of a multimember district, it might be argued, is its tendency to frustrate the choice of a substantial number of voters -a group which by virtue of its size and concentration could elect the candidate of its choice in a single district-while allowing the individual voters in the group full access to the political process. In short, plaintiffs had complained that the electoral deck was stacked against them. The Court answered that there was no valid complaint because plaintiffs had been let into the game. The answer hardly seems responsive.

The opinion next found the plaintiffs' attack deficient in failing to show "recurring poor performance by Marion County's delegation with respect to [the] ghetto." ${ }^{94}$ It noted plaintiffs' concession that on some issues the interests of ghetto voters coincided with those of other district voters; as to these, there assumedly was no underrepresentation. As to other issues, where the interests might be expected to diverge, the Court saw no evidence of poor representation or any reason to believe that the outcomes of particular legislative issues would have been any different had all representatives been elected from single member districts.

At this point the opinion establishes an impossibly high standard of proof. How could "poor performance" of legislators "with respect to the ghetto" accurately be gauged? Short of extremely difficult procedures-such as comparing the results of issue-by-issue polls conducted in the ghetto with legislators' votes on those issues, or similarly unrealistic methods--even a very subjective assessment of "poor performance" could not be made. It is an unworkable test. Even more unlikely, if not impossible, is proof that the outcomes of various legislative issues would have been different had representatives been elected from single member districts. Nor should plaintiffs be required to bear such a burden. ${ }^{95}$ Furthermore, the Court hinted that even if the district delegation consistently opposed the ghetto's views, there would be no constitutional deprivation. ${ }^{\mathbf{6}}$

94 Id. at 155 .

95 One supposes that even the plaintiffs in the Reapportionment Cases would have been hard pressed to show that the outcomes of particular legislative skirmishes would have been different under different plans of representation. Further, the opinion of the Court nowhere even intimates how plaintiffs could make such a showing. Justice Harlan's separate opinion remarks of this and the "poor performance" tests: "If there are less appropriate subjects for federal judicial inquiry, they do not come readily to mind." 403 U.S. at 170 .

$96 I d$, at 155 . 
The Court also rejected plaintiffs' theory as being potentially too broad:

It is expressive of the more general proposition that any group with distinctive interests must be represented in legislative halls if it is numerous enough to command at least one seat and represents a majority living in an area sufficiently compact to constitute a single-member district. ${ }^{97}$

Such a principle would, the Court felt, open courts to complaints of submergence from any sizable interest group-including political parties, union oriented workers, religious groups-occupying identifiable areas. The approach urged by plaintiffs " $[\mathrm{a}] \mathrm{t}$ the very least . . . would spawn endless litigation." 98 An answer to this argument is that the Supreme Court might reasonably limit its concern to cases involving claims of racial discrimination. Particularly in light of recent Supreme Court decisions recognizing that "the core of the Fourteenth Amendment is the prevention of meaningful and unjustified official distinctions based on race . . . " " 99 these claims present the strongest arguments for judicial intervention. Moreover, the threat of "endless litigation" will be further limited if plaintiffs are required to show that the result of a districting scheme is only a short step away from the more obvious, analagous forms of exclusion from the political arena. These requirements still would leave sufficient obstacles in the way of frivolous claims and would effect a more conscionable balance between concern for judicial resources and equal opportunities to gain legislative representation.

This section has suggested that the district court found for plaintiffs on an insufficient evidentiary base while the Supreme Court ruled against them under an impossibly high legal test. It is appropriate now to consider what should be the legal standards governing such cases, and what proof is necessary to satisfy those standards. To do this, it is necessary to uncover the doctrinal supports for attacks on multimember districts.

\section{Precedents and Problems of Proof}

In neither Fortson nor Burns, the two leading multimember district cases prior to Chavis, did the Court set out reasons for its dicta regarding submergence. Nonetheless, since Chavis did not overrule these cases, and indeed quoted from both, further analysis requires a

97 Id. at 156.

$98 I d$. at 157.

99 James v. Valtierra, 402 U.S. 137, 141 (1971) (quoting Hunter v. Erickson, 393 U.S. 385, 391 (1969)). 
search for precedents underlying the Supreme Court's hint that minimization of a racial bloc's voting strength could be constitutionally prohibited. This section reviews some of the most germane precedents and concludes that although they broadly support the proposition that a claim of racial submergence gives rise to a cause of action, the available authority is insufficient to determine the nature, burden, and sufficiency of proof. Whether in certain limited instances the courts should invalidate the use of multimember districts is then considered.

Plaintiffs presenting a case such as Chavis claim that discrimination in apportionment submerges the voting power of a racial group. The doctrinal origins for a cause of action of this nature, and for the Fortson-Burns dicta, are thus to be sought in apportionment and racial discrimination cases. Voting rights cases, which relate to the issue of access to the ballot box (an issue that the Supreme Court did not recognize as existing in Chavis), offer little guidance on the fourteenth amendment problems raised here. We will therefore limit our inquiry to the other two classes of cases. The focus will be upon assessing to what degree they support the proposition that minimization of a racial group's voting strength is constitutionally prohibited.

\section{A. The Reapportionment Cases}

A broad reading of the reapportionment cases might support a prohibition of multimember districts where they submerge a cognizable racial element. ${ }^{100}$ In Reynolds, the requirement of equal representation could be interpreted to mean that, in a representative system, voting plans must result in the election of representatives who truly represent at least the larger, identifiable groups in the population. Taken to its most logical extreme, this argument would require proportional representation.

This broad reading is highly speculative because in those reapportionment cases where plaintiffs prevailed the decisions were based solely on population variances. ${ }^{101}$ No factors other than population have been raised to the level of constitutional imperatives. ${ }^{102}$ And, with the exception of Gomillion v. Lightfoot, ${ }^{103}$ in which there was overt

100 See text accompanying note 55 supra.

101 See, e.g., cases cited note 9 supra. See also Democratrc Representation, supra note 2 , at 449 .

102 Although Reynolds did mention certain factors other than population-such as maintaining the integrity of political subdivisions, providing for compact districts of contiguous territory, and having due regard for natural or historical boundary lines, 377 U.S. at 578-79-which might validly be considered in drawing legislative district lines, these factors provide defenses to the state rather than theories of attack to plaintiffs. Moreover, the Court has never gone much beyond paying lip service to these factors. See id. at 580 .

103364 U.S. 339 (1960). 
racial hostility evidenced by redrawing of city boundaries excluding virtually all blacks from the city, the Court has refused to apply race as a proper basis for gauging the constitutionality of an apportionment plan. ${ }^{104}$ Hence, while it may be argued that the general principles of fairness and equal representation underlying the reapportionment cases are not unfriendly to claims against racially discriminatory districting in the multimember district setting, and perhaps even would be theoretically supportive, the cases on their facts do not provide much direct help. And, even if one assumes that Reynolds would prohibit racially submerged districts under an extended theory of equal representation, it provides no guidance as to when a racial group is submerged.

In one reapportionment case, however, the Court did encounter an attempt to create a representation standard based upon the prohibition against racial discrimination. Although plaintiffs did not succeed in either the district court or the Supreme Court, the case provides a very relevant background for discussing representation theory and constitutional requirements pertaining to race and fair representation.

In Wright $v$. Rockefeller, ${ }^{105}$ the plaintiffs, who were black and Puerto Rican voters residing on Manhattan Island, alleged that the Island's congressional district lines had been drawn with the intent of placing black and Puerto Rican voters mainly within the Eighteenth Congressional District and keeping them out of the "silk stocking" Seventeenth District. ${ }^{106}$ Plaintiffs objected to these racially segregated voting districts, although the precise constitutional theory they advanced was not entirely clear. ${ }^{107}$ The three-judge district court rejected plaintiffs' claim in a two-to-one decision, but the three opinions left unresolved many questions regarding the applicable standard. Two judges would have found for plaintiffs upon a showing that the districts had been created along racial lines, while the third would have required in

$104 \mathrm{It}$ is questionable, indeed, whether Gomillion can properly be considered as an apportionment case. It was really more of a total disenfranchisement-at least as far as voting for offices in the City of Tuskegee was concerned. See Democratic REPRESENTATION, sipra note 2 , at 116-17.

105211 F. Supp. 460 (S.D.N.Y. 1962), aff'd, 376 U.S. 52 (1964).

106 Although the Seventeenth and Eighteenth Districts shared a considerable boundary, it seems undeniable that concentration of voters by race would have existed under any reasonable apportionment: such is the high ghettoization of upper Manhattan Island. Plaintiffs apparently objected to what appeared to be official efforts to keep the Seventeenth District almost completely white. Id. at 461, 464.

107 Unilike the situation of racially segregated schools or parks, the harmful effects of racially segregated voting districts are not apparent. As Judge Moore wrote in his opinion in the district court:

Plaintiffs' theories of unconstitutionality are difficult to pin down. . . . [P]laintiffs ask this court to conclude .. . that the Legislature in $1961^{\circ}$ drew the district lines so as to intentionally deprive non-whites and Puerto Ricans of their constitutional rights. "Constitutional rights" to do what still remains unanswered.

Id. at 465 . 
addition a specific showing of harm in the form of dilution of the plaintiffs' right to vote. Only one judge felt that a showing of racial line drawing had in fact been made. The Supreme Court affirmed, agreeing with the finding of two judges in the district court that plaintiffs had not met their burden of proof on the issue of racial line drawing.

Wright is important for two reasons: 1 ) it reaffirms that in legislative districting cases, courts would be willing to step in if plaintiffs could sustain an allegation of line drawing based on race-a clear implication that extended from the earlier case of Gomillion v. Lightfoot; and 2) it raises the question whether race can be considered in drawing districts to remedy a previously discriminatory districting scheme. Given that Gomillion forbids districting intended to harm blacks, can racial lines be drawn with the intent to help them? On the latter point the analysis in Wright was remarkably sparse. None of the seven opinions (three in the district court, four in the Supreme Court) even intimated that a fair representation standard might require a legislature to take race into account in drawing district lines, to insure that racial interests would be fairly represented. ${ }^{108}$ The dicta of Fortson implies that just such an accounting must be taken if necessary to avoid submergence. For if submergence is a remediable harm, it is doubtful that in all cases it will be remedied by a random districting scheme. ${ }^{100}$

Why did the Wright court not consider that race might be a relevant guide for line drawing? The reason is found in the history of racial equal protection cases. That history had largely been directed toward taking race out of the legal picture wherever possible, toward making the Constitution color blind.110 Thus, although the Wright majority in the Supreme Court was content to affirm on the ground that plaintiffs had not met their burden of proof, Justice Douglas would have reversed the lower court because he believed the lines drawn could be explained only in racial terms ${ }^{111}$ and "[r]acial segregation that is

108 Rather, it was assumed that any such consideration would be prohibited. See, e.g., Judge Feinberg's dismissal of intervenors' argument that changing district lines would jeopardize non-white control of one district as "irrelevant" (quoting the first Mr. Justice Harlan's statement that the Constitution is color-blind). $211 \mathrm{~F}$. Supp. at 469 \& n.7. See also note 109 infra.

109 Although plaintiffs objected to the use of race as a districting factor, Judge Moore noted that any remedial plan would have to consider race if its aim was to achieve racial balance between districts. He suggested this would "verg[e] upon the unconstitutional." 211 F. Supp. at 468. See Mann v. Davis, 245 F. Supp. 241, 245 (E.D. Va.), aff'd mem. sub nom. Burnette v. Davis, 382 U.S. 42 (1965) ("Certainly [one man-one vote] does not demand an alignment of districts to assure success at the polls of any race. No line may be drawn to prefer by race or color.")

110 Plessy v. Ferguson, 163 U.S. 537, 559 (1896) (Harlan, J., dissenting).

111376 U.S. at 59. The evidence cited by Justice Douglas, id. at 59-61, strongly supported the inference of racial line drawing. 
state-sponsored should be nullified whatever may have been intended." 112

Despite the circumscribed viewpoint of the judges who decided $W$ right, the possibility that a court, once it looked into a racial challenge to the composition of a voting district, might find a requirement that race be taken into account, was not lost on some commentators. Robert Dixon wrote:

From Wright comes this overriding question- . . . To what extent is it constitutionally permissible, proper, or perhaps necessary in representation theory, to create homogeneous "communal constitutencies [sic]"? 113

Hence, the importance of Wright to our study rests more on the issue it suggested than on the issues it decided. The Court had for the first time at least brushed against the issue of fair representation-representation theory beyond mere mathematical equality of districts.

The issue raised in Wright is particularly relevant when attempting to fashion a remedy for a districting scheme previously adjudged unconstitutional. The issue of affirmative use of race as a legislative criterion arises both in districting plans invalidated solely on the basis of unconstitutional intent and in districting plans when de facto submergence is an issue. In either case the question of the remedial use of race presents itself in fashioning a remedy once the unconstitutionality of the districting scheme is established.

\section{B. The Desegregation Cases}

It may be argued that the desegregation cases stand for the broad proposition that any government action which is racially discriminatory is presumptively invalid. ${ }^{114}$ This is not an unreasonable reading of Brown v. Board of Education ${ }^{115}$ and its progeny, especially in light of the series of per curiam decisions after Brown which invalidated racial

112 Id. at 61 .

113 Democratic Representation, supra note 2, at 467. See also Note, Wright v. Rockefeller and Legislative Gerrymanders: The Desegregation Decisions Phts a Problem of Proof, 72 Yale L.J. 1041, 1056 (1963) :

[I]f the fact of racial homogeneity is regarded as the constitutional evil, state legislatures are forced to employ racial criteria in drawing district lines so as to avoid a constitutionally impermissible, or even constitutionally suspect, grouping of members of the same race. Thus . . the use of factors such as race becomes mandatory rather than forbidden.

The writer, however, criticizes the result as "anomalous."

114 See Note, Wright v. Rockefeller and Legislative Gerrymanders: The Desegregation Decisions Plus a Problem of Proof, 72 YaLE L.J. 1041, 1049 (1963).

115347 U.S. 483 (1954). 
segregation in many types of public facilities. ${ }^{116}$ Such a broad proposition, however, is of little practical use. Presumably, Wright and Gomillion have already shown that deliberate drawing of racial districts with the intent of harming blacks is impermissible. ${ }^{117}$ Although Brown goes further (separate school systems are forbidden whether or not they were intended to harm blacks), in the absence of racial intent how are we to tell whether the effect of a multimember districting scheme will be racially discriminatory?

Indeed, on one level the desegregation cases do not serve Chavistype plaintiffs well. The classic form of racial discrimination has involved the segregation of the races whereas a multimember district plan is ostensibly a combining of the races. ${ }^{118}$ The desegregation cases after Brown did not require specific proof of harm because harm was presumed from the fact of separation. The same conclusion cannot be assumed for a multimember district because the races are grouped together.

The desegregation cases may, however, be useful in a more general sense. The core of plaintiffs' complaints in those cases rested upon the

116 E.g., Mayor of Baltimore v. Dawson, 350 U.S. 877 (1955) (mem.) (public beaches and bathhouses); Holmes v. Atlanta, 350 U.S. 879 (1955) (mem.) (municipal golf courses); Gayle v. Browder, 352 U.S. 903 (1956) (mem.) (public transportation); New Orleans City Park Improvement Ass'n v. Detiege, 358 U.S. 54 (1958) (mem.) (parks) ; State Athletic Comm'n v. Dorsey, 359 U.S. 533 (1959) (mem.) (rule forbidding interracial boxing struck down); Johnson v. Virginia, 373 U.S. 61 (1963) (per curiam) (court rooms).

117 Brest, Palmer y. Thompson: An Approach to the Problem of Unconstitutional Legislative Motive, 1971 SuP. Cr. REv. 95, 99-102; Ely, Legislative and Administrative Motivation in Constitutional Law, 79 YALE L.J. 1205, 1268 (1970). But see Palmer v. Thompson, 403 U.S. 217, 224 (1971) ; United States v. O'Brien, 391 U.S. 367, 383 (1968). The Court's reluctance to look to motive to invalidate legislative enactments is so great that it has stated repeatedly in recent years that, "It is a familiar principle of constitutional law that this Court will not strike down an otherwise constitutional statute on the basis of an alleged illicit legislative motive." United States v. O'Brien, 391 U.S. at 383 . This bit of wisdom has not been lost on the lower courts. See Bulluck v. Washington, No. 24,862, at 7-11 (D.C. Cir., Jan. 19, 1972). The familiarity of this principle does not establish its immutability. Indeed, in a number of cases the Court, despite its disclaimers, clearly did rely on a motivation test. See Epperson v. Arkansas, 393 U.S. 97 (1968); Gomillion v. Lightfoot, 364 U.S. 339 (1960). And, in other cases, had illicit motive been shown, the opinions of the Justices suggest that they would have gone the other way. See Palmer v. Thompson, 403 U.S. 217 (1971); Wright v. Rockefeller, 376 U.S. 52 (1964). Furthermore, it has been suggested in the context of Gomillion that intent is the most appropriate criterion in a racial districting case. See Ely, supra at 1268. This theory obviates the need to prove harm. In light of the great difficulty of defining and proving harm in a districting case, it might be the only viable criteria. Nevertheless, the Court has not generally phrased the issue solely in terms of intent. And even if intent is sufficient to invalidate a districting scheme, harm may still have a place in the scheme of analysis. This is clearly implied by Fortson and Burns. The questions of what harm is and when it should trigger judicial intervention remain.

118

[I]n terms of results, spreading Negroes or other minorities may help them educationally, but may hurt them politically in terms of safe seats. Racial desegregation cases therefore may yield unappealing precedents for racial gerrymandering cases.

Democratic Representation, supra note 2 , at 469. 
harm suffered by blacks in the areas of education and enjoyment of public facilities. Government enforced segregation ${ }^{119}$ is virtually tantamount to that harm because of the unavoidable consequences of such segregation. ${ }^{120}$ The minority race is branded as inferior; psychological harm to individuals of the minority results and the entire social group is adversely affected. ${ }^{121}$ This reading of the desegregation cases would allow a cause of action upon any showing of harm resulting from race. Of course, since there is no separation of the races-which would make the case easy-there remains the necessity of showing actual harm. ${ }^{122}$ And, we are again led to the fundamental question of what constitutes harm (or submergence in the multimember district context). Thus, in the multimember district situation, to determine whether discrimination existed the Court would have to decide whether blacks within the district are harmed, by in some sense being unfairly represented in the legislature. The recurring nature of this question of what constitutes harm requires that we examine that aspect of the problem in greater detail.

\section{Proof of Harm: Theoretical Obstacles}

When a voter participates in a multimember district election, his vote influences the outcome of the election of more than one legislator. Although there may be some disparity between a voter's power in a multimember district vis-à-vis a voter in a single member district, ${ }^{123}$

119 This discussion relates only to the desegregation cases; it is not concerned with those cases where states or cities denied entirely the use of certain public facilities to Negroes.

120 Cf. Brown v. Board of Educ., 347 U.S. 483, 494 \& n.11 (1954).

121 See, e.g., id. at 494, quoting an uncited lower court opinion:

"Segregation of white and colored children in public schools has a detrimental effect upon the colored children. The impact is greater when it has the sanction of the law; for the policy of separating the races is usually interpreted as denoting the inferiority of the negro group., A sense of inferiority affects the motivation of a child to learn. . . ."

122 Recent cases highlight a problem of proof of harm in housing discrimination law that is similar to the problem of proof of harm in voting discrimination law. In Reitman v. Mulkey, 387 U.S. 369 (1967), the Court held that the repeal of fair housing laws via state constitutional amendment violates the fourteenth amendment. Subsequently, in Hunter v. Erickson, 393 U.S. 385 (1969), it held that the establishment of requirements for enactment of fair housing laws beyond the requirements for other legislation is also invalid. Yet in James v. Valtierra, 402 U.S. 137 (1971), the Court refused to invalidate a California constitutional provision that required referendum approval by the locality before any low income public housing could be built. The Court distinguished Hunter on the ground that the law struck down in that case created a "racial classification." The constitutional provision in Valtierra on the other hand did not rest on "distinctions based on race." 402 U.S. at 141 (quoting Hunter v. Erickson, 393 U.S. at 391). But who can doubt that the frequent effect of the provision upheld in that case is seriously to disadvantage racial minority groups? It should not be determinative that the challenged law does not create racial classification on its face.

123 Banzhaf, Multi-Member Electoral Districts-Do They Violate the "One Man, One Vote" Principle?, 75 YALE L.J. 1309 (1966). 
the Court has held that this difference, standing alone, is not enough to invalidate multimember districts. ${ }^{124}$ That multimember districts are not unconstitutional per se reflects the view that the Court is in no position to judge whether it is better from the voter's point of view to influence many legislators in a small way or one legislator to a relatively more substantial extent. For example, suppose five years from now there is a split in the nonghetto faction of Marion County's electorate. Might not the ghetto voters then hold the key to the election of all legislators in the multimember district? Given the right set of political circumstances, today's minority may tomorrow exercise a voting influence vastly out of proportion with its numbers. Should the Court then strike down the districting scheme because it overemphasizes the ghetto's political power at the expense of the rest of the district? Admittedly, the hypothetical is unlikely to occur in the immediate future, but is it so unlikely that the Court can confidently strike down the multimember district as inherently discriminatory? In short, a voter in a multimember district has a small impact on many legislators. A voter in a single member district has (in a relative sense) a large impact on one legislator. The Court cannot say, as a matter of constitutional law, that the position of a voter in the single member district is always preferable. ${ }^{125}$

In the face of such enigmatic considerations it would be easy (and perhaps wise) for courts to refrain from announcing reapportionment standards beyond the one man-one vote guideline. What one considers to be the proper outcome of a claim of racial districting will vary according to one's theory of political representation. A group of voters that influences many legislators in a small way is not inherently less desirable than a group that has a large impact on one legislator. Indeed, when the other voters in a district in which the blacks constitute

124 Fortson v. Dorsey, 379 U.S. 433 (1965).

125 Cf. Jewell, Commentary, in Reapportionment in the 1970s 46, 48 (N. Polsby ed. 1971). This problem of voter impact carries over to another possible districting scheme. Assume a city in which $40 \%$ of the voters are black and live in a relatively compact and contiguous part of the city. The city elects 10 legislators and the state uses single member districts only. Clearly, the city could be districted in a fashion leading to 4 predominantly black districts with blacks having very few voters in other districts. Alternatively, the city may be districted in a fashion leading to blacks comprising about $40 \%$ of each district and nonblacks about $60 \%$ of each district. This latter situation is analogous to creating a multimember district large enough to insure that blacks constitute a minority. If voting went along racial lines, blacks would elect no representative under this scheme and 4 representatives under the former districting scheme. Which is preferable? Again, there is no simple answer. The choice is between the ability to influence significantly one legislator or to partially influence many. If the Court opts for one choice today, it may face plaintiffs demanding the other in a case tomorrow. Chavis and Wright v. Rockefeller illustrate the dilemma. In Wright, plaintiffs complained that Manhattan was districted to create 1 black district and 3 white districts. Yet in Chavis that is precisely the type of districting plaintiffs requested. 
a minority are in a state of political equilibrium, it may be that the black group will wield political clout disproportionately large for its numbers.

The difficulties in developing a judicially applicable standard for claims of racial harm (that is, submergence) in multimember districting schemes argue strongly for courts abstaining from districting cases in which the districts conform to the one man-one vote standard. But if the Court plans such a principled abstention from the racial gerrymander field it has not articulated its intention. In no case involving claims of racial districting has the Court cut off the avenue of judicial redress-a step it could take by invoking the political question doctrine, for example. Rather, the decisions, which have uniformly upheld the extant districting schemes, ${ }^{126}$ have been based on other grounds. The Court may, in fact, be refraining from entering the field by the expedient of case by case decisions like Chavis, which are unresponsive to the more troublesome issues. Indeed, one reading of Chavis may preclude attacks on multimember districts where racially motivated districting is not alleged. The Court in Chavis said that plaintiffs' theory, if successful, might require that all sufficiently large cognizable groups within a district be represented-a result the Court was wholly unprepared to accept. This barrier raises the question whether a middle ground can exist between the position that would allow attacks on multimember districts only when illicit legislative motive is alleged and the position that would allow attacks when a sufficiently large group is submerged (harmed) - the position the Court rejected in Chavis. Arguably, Fortson and Burns suggest that such a middle ground can exist.

Is there a narrow class of cases where the Court could say, regardless of legislative intent, that a multimember districting scheme operated unconstitutionally? To put it in the language of Fortson: when does a "multimember constituency apportionment scheme . . . operate to minimize or cancel out the voting strength of racial or political elements of the voting population"? One may ask why we bother to search for such a class of cases when none has yet been found in practice. Perhaps the search is futile, but the notion that such cases may exist is explicit in Fortson and Burns and implicit in Chavis. For if by the time of Chavis the Court had decided to make intent the only relevant factor in attacking multimember districts, that case provided a perfect opportunity for enunciating such a rule. Yet the Court announced no such rule. Assumedly, the doctrine of submergence still exists, and such submergence is a provable harm.

One set of principles that should be examined in the search for support of the view that submergence is a legally cognizable harm is the

126 Gomillion, which involved motivation, is an exception. 
three-part test suggested by Burns. Unfortunately, that test is only coincidentally related, if at all, to the constitutional bases of a complaint charging racial submergence. The Supreme Court tacitly admitted as much by reversing the district court in Chavis despite the lower court's unarguable finding that the facts satisfied all three parts of the Burns test. ${ }^{127}$ Burns was a case that did not involve charges of racial submergence, and is of dubious relevance to the real problems encountered in litigation challenging multimember districts on racial grounds.

Those problems center around representation of racial interests: are citizens who, by virtue of their race and other characteristics, are considered to make up a legitimate voter group represented fairly under a given apportionment of legislators? The Burns standard does not help in answering this question.

The first part of the test said that the "invidious effect can more easily be shown if . . . districts are large in relation to the total number of legislators ...." However, if defendants could establish that under a given multimember district plan the elected representatives did in fact represent all electors fairly, it would not matter if the district was fairly large. Perhaps the Court felt that large districts would lead to unequal representation, but there is no apparent reason for such an assumption. Of course, one could assume that the Court was really implying that although multimember districts by nature discriminate against minority groups they will be tolerated as long as they are not too large (that is, as long as they do not discriminate too much). Such an assumption would be unwarranted. That approach is contrary to specific holdings of earlier cases; it is also a poor way to undertake constitutional decisionmaking. Or, one could assume that the Court desired to protect electors outside the multimember district, and thus limited the size of the "bloc" which could be created. This seems to be a genuine problem, but it is not related to the representational problems that are at the core of a racial submergence case.

The second part of the Burns test suggested that if districts were not appropriately subdistricted ${ }^{128}$ to assure distribution of legislators, such districts might be found unconstitutional. This requirement has the most relation to fair representation of all three parts of the Burns standard. Yet even compliance with this test may yield negative results. Candidates from within a subdistrict may very well be unrepresentative of the district, and those from outside it may give eloquent

127305 F. Supp. at 1386-87.

$128 \mathrm{~A}$ subdistrict is the area in which a candidate for office in a multimember district must reside. The establishment of seats for each subdistrict theoretically assures representation for each area of the larger multimember district. In reality, it assures only that the elected representatives will live in the different areas, not that they will be representative of those areas. 
voice to its concerns. In Chavis, for example, one of the plaintiffs was a black attorney, active in ghetto affairs and with an office in the ghetto, who had served as a representative from Marion County-and who resided outside of the ghetto defined by the court. Arguably, he would be a better, though non-resident, ghetto representative than a ghetto resident handpicked to run by the party machine because of his obedience to the party or his attractiveness to non-ghetto voters. Perhaps courts should take residence requirements into account when trying to determine how fair a representation plan is, but residence should not be a dispositive criterion.

The last test suggested unconstitutionality if "[multimember] districts characterize both houses of a bicameral legislature rather than one." As with the first standard, this does not tell us very much about how good a job of fairly representing the people a certain plan does. If it does a very good job, it is hard to see why both houses should not adopt it. Perhaps the Court felt that it is so difficult to determine when representation is fair that it would concentrate on whether appropriate checks existed within the system to keep it from becoming too one-sided. Hence, the use of multimember districts would be restricted to one house of the state legislature. In Burns, the Court feared that the Hawaiian plan "built monoliths" into the legislature because multimember district lines were the same for both houses. The suggestion that the Court was merely trying to insure that there would be a counterweight to the possible bad effects of multimember districts in one house (by forbidding them in the other) would then justify the test in the Burns situation, when multimember district lines coincided for both houses of a state legislature. However, this qualification narrows the applicability of the test considerably. Further, it is premised on the notion that since courts cannot really assess whether representation is "fair," they should try to steer a middle course; this is not a sufficient justification for voiding state action that otherwise may be entirely justified by state policy.

\section{Proof of Harm: A Practical Showing of Racial Submergence}

That we encounter some difficulty in articulating a submergence rationale should not be surprising. Litigation concerning multimember districts presents some of the most difficult questions in the reapportionment field. Typically, it will involve districts that comply with the equal population mandate of Reynolds; indeed, many legislatures see the use of multimember districts as a means of achieving compliance with Reynolds while still retaining "bloc" representation for a unit (for 
example, a large city) that is larger than a single member district. ${ }^{129}$ Further, there may be no evidence that the legislature acted with impermissible intent; ${ }^{130}$ indeed, in some cases, the purpose of the whole plan may be to insure the representation of interests that otherwise might go unarticulated (for example, city or areawide interests). ${ }^{131}$ These facts indicate that multimember districts may serve legitimate state interests. Further, there may be blacks opposing the action ostensibly brought in their name by black plaintiffs, ${ }^{132}$ or there may be plaintiffs whose claims are complicated by the inclusion of political as well as racial challenges to the multimember district scheme. ${ }^{133}$ Finally, even once the interests are identified and the case is reduced to its racial components, courts will be faced with difficult questions as to the appropriateness and fairness of competing apportionment schemes. ${ }^{134}$ These and related problems argue strongly for judicial caution in assessing claims of racial submergence and in formulating remedies.

To insure that the state's legitimate interests in having multimember districts are indeed outweighed by plaintiffs' interests, and that merely political disputes are screened out to the greatest extent possible, courts should demand at least an initial twofold showing by plaintiffs in such cases. First, it must be shown that in the challenged multimember district there is a cognizable racial group which is in a minority in the district yet which is sufficiently large to elect a representative in a single member district allocation of seats. This requirement limits the ranks of potential plaintiffs to those who have been actually harmed by the multimember district plan ${ }^{135}$-those who but for the challenged scheme could have elected a representative of their own choosing.

Secondly, courts should require a showing that this specific racial group is cohesive in terms of political viewpoints and substantially in opposition to voter groups in the rest of the district. The words are

129 Kilgarlin v. Martin, 252 F. Supp. 404 (S.D. Tex. 1966), aff'd stub nom. Kilgarlin v. Hill, 386 U.S. 120 (1967).

130 See, e.g., Mann v. Davis, 245 F. Supp. 241 (E.D. Va.), aff'd mem. sub nom. Burnette v. Davis, 382 U.S. 42 (1965).

131 Kilgarlin v. Martin, 252 F. Supp. 404, 443 (S.D. Tex. 1966), aff'd sub nom. Kilgarlin y. Hill, 386 U.S. 120 (1967).

132 See, e.g., Wright v. Rockefeller, 211 F. Supp. 460 (S.D.N.Y. 1962), aff'd, 376 U.S. 52 (1964).

133 See, e.g., Mann v. Davis, 245 F. Supp. 241 (E.D. Va.), aff'd mem. sub nom. Burnette v. Davis, 382 U.S. 42 (1965).

134 The conflict will be between those who favor the single member district because it can assure the racial group a safe seat, and those who favor the multimember district because it leaves the group with an influence over a number of seats. See M. Jeweli, Metropolitan Repressentation: State Legislative Districting in URBAN Coun'tres 15-18 (1969); Wright v. Rockefeller, 211 F. Supp. 460 (S.D.N.Y. 1962), aff'd, 376 U.S. 52 (1964); note 113 supra \& accompanying text.

135 This limitation serves to answer partially the Court's concern in Chavis that a contrary result would give rise to endless litigation. See text accompanying notes 97-99 supra. 
necessarily imprecise, but the outline of their meaning should be clear: to imply that they have lost something, plaintiffs must show that there is something to lose and that they are in a position to lose it. What they have to lose is the chance to elect a representative of their choosing -but if they have such internally diverse views that this is a practical impossibility, there is no real loss occasioned by the multimember district plan. Likewise, if they are internally cohesive but are not politically dissimilar from those who surround or have the power to outvote them, there is no loss since presumably the candidates they favor will also be favored by the outsiders.

To make this second showing would be difficult. It should be, for the courts are being asked to come very close to concerns that are usually in the legislature's domain. Hence, the showing of submergence should be clear. Further, to undertake this showing, plaintiffs must engage in inquiries that bring courts near the center of political disputes. Such a showing requires, for example, evidence on the political makeup of the district. Though such inquiries must be undertaken cautiously, there are categories of evidence which courts may be willing to accept as presumptively establishing internal cohesiveness and external conflict. This would include evidence of the type entertained by the district court in Whitcomb $v$. Chavis: detailed studies of race, housing, social and economic characteristics of both the internal (ghetto) area and the remainder of the multimember district. If great disparities are found, this evidence would indicate that the racial minority group had "compelling interests in [many] legislative areas" not shared outside of the ghetto. ${ }^{136}$

This should not settle the matter, however, as it apparently did for the district court in Chavis, ${ }^{137}$ for there has been no actual showing of submergence. So far, the evidence logically creates no more than a presumption. Defendants ought to be allowed to rebut the presumption of submergence by showing in fact that the minority is being represented. This too would be difficult, but not impossible. Defendants would have to show both that the minority has a fair chance to make its will known and that the minority's will is fairly represented.

The minority's political will can be gauged in a number of ways. For example, if party primaries are held in the multimember district, results of these elections could be tabulated for the ghetto to determine the minority's choice of candidates. The "purity" of the choice would be even greater if the political parties were not allowed to endorse candidates in the primaries. If primaries are not held, separate tabulations

136 Chavis v. Whitcomb, 305 F. Supp. 1364, 1380 (S.D. Ind. 1969).

137 See text accompanying notes 74-76 supra. 
after the general election would indicate, although to a lesser degree, the drift of the popular will in the ghetto area.

Once a suitable method is found for determining the will of the people in the minority area, it is then necessary to decide whether that segment of the popular will is being fairly represented. This too could be done in a number of ways. The simplest would be to compare the results of primary elections in the minority area with results from the general election districtwide. If those candidates who do well in the ghetto in the primary are not successful in the general election in rough proportion to the ghetto's size within the whole district, a question of racial submergence arises. The case would be even stronger where candidates popular in the ghetto in the primary are not even allowed to enter the general election because the ghetto's vote is overridden by the outside vote. If, however, the minority area is getting its share of representatives, defendants would prevail.

Candor requires the admission that the suggested line of analysis does not avoid Chavis and all its implications. The Court in Chavis feared a result that would allow any large cohesive group to have a cause of action against a multimember districting plan. Hopefully, the proposed test severely limits the classes of plaintiffs that could present a justiciable claim. But it may be difficult to limit the cause of action to racial groups. When nonracial groups are submerged within a multimember district they arguably are entitled to the same relief proposed above for blacks. Fortson, after all, spoke in terms of "racial or political" interests being diluted. An argument can be made, with historical support, that the fourteenth amendment applies more stringently to racial discriminations than to other classifications. Yet it seems improbable that the Court would expressly acknowledge the application of a different submergence standard to, for example, a claim of Protestant submergence than to a claim of black submergence. Perhaps a line can be drawn to exclude those who assert a political group's submergence by use of the political question doctrine, ${ }^{138}$ but that is not a wholly satisfactory result. After all, if Republicans could have elected someone more sympathetic to their views in the absence of a multimember district, ${ }^{139}$ are they not suffering the same harm blacks suffer in the cases for which we wish to grant relief? Certainly in the case of de facto racial submergence, where racial intent is not shown, blacks are not suffering because they are black.

138 This has been suggested by a few cases. See Sims v. Baggett, 247 F. Supp. 96, 104 (M.D. Ala. 1965) (dictum) (3-judge court); cf. Sincock v. Gately, 262 F. Supp. 739, 833 (D. Del. 1967) (3-judge court).

139 See note 78 supra. 
A second objection that can be leveled at the suggested submergence standard is that the requisite internal cohesiveness and uniformity of interests can rarely, if ever, be found. Presumably a substantial period of uniformity is necessary to enable plaintiffs to make their case. During that period, however, people have died, others have left the district, and others have changed their views. Although this complicates the factfinding process it should not, standing alone, preclude a finding of uniformity. Perhaps more troublesome to a finding of political uniformity is the decision of what issues are properly indicative of uniformity. Groups are politically identifiable primarily on an issue or interest basis, and constituencies may change constantly with the issues. Yet it is likely that the district court's finding in Chavis that there existed a cognizable group with similar legislative interests on a broad spectrum of issues reflected the situation in the Center Township ghetto with substantial accuracy. More importantly, the analysis suggested in this paper serves to focus on what should be the two elements of plaintiffs' case: 1 ) that the minority's will is X; and 2) that $X$ does not have a fair proportion of spokesmen in the legislature. Over these questions should the charge of racial submergence be fought.

\section{ConCluston}

Since the reapportionment revolution began in 1962, the equal populations standard has been the sole determinant of a given apportionment scheme's constitutionality. In cases involving challenges to multimember districts, the Supreme Court had appeared ready to move away from equal populations as the only permissible standard, giving rise to the expectation that it would begin to consider not only whether representation under a given plan was equal but also whether it was fair. The Court has not yet taken that step, however, and has recently shown a reluctance to do so.

We have explored a mixture of possible rationales under which the Court could sustain submerged groups attacking their multimember districts. Admittedly, none of the tests has been wholly satisfactory. There is a possible theoretical barrier to finding harm. And, even if one is able to surmount this obstacle, harm in the context of a particular case is extremely difficult to prove. Furthermore, the test for harm has disturbing implications and may be logically extended to nonracial submergence.

Nonetheless, the quest for standards of fair representation beyond mere equality of district size is an appropriate undertaking under the Court's precedents and, because the Court has refused to declare that such cases are inherently unmanageable, holds some promise of success. 
That promise can be realized if the Court requires a high, yet attainable, standard of proof directed at showing that an apportionment plan frustrates the choice of a large, cognizable minority group which, but for the multimember district arrangement, would be able to obtain the representation it desires. 